\title{
Effect of Drying Temperature and Natural Fermentation on the Phytochemical Composition of Stinging Nettle Buds (Urtica parviflora)
}

\author{
${ }^{a}$ Babita Adhikari*, ${ }^{a}$ Smriti Ale \\ aDepartment of Food Technology, Central Campus of Technology, Tribhuvan University, Dharan, Nepal \\ *Corresponding email: babita.adhikari@cct.tu.edu.np
}

\begin{abstract}
Stinging nettle (Urtica parviflora), locally known as sisnu in Nepal, is rich in phytochemicals. Phytochemical are non-nutritive bioactive chemical compounds found naturally in plants; possess antioxidant activity and reduce the risk of different diseases by serving structural and functional role as well as an electrolyte. The effect of drying temperature $\left(50,60,70^{\circ} \mathrm{C}\right)$ and natural fermentation $\left(24 \pm 1^{\circ} \mathrm{C}\right.$ for 15 days $)$ of fresh nettle buds on the phytochemical composition (polyphenol, tannin, flavonoid and antioxidant activity) were studied. The phytochemical screening of the samples was carried out using $80 \%$ ethanol through maceration technique. The tannin, flavonoid, total phenol content and antioxidant activity in ethanolic extract of fresh nettle buds were found to be $1.02 \pm 0.08$ $\mathrm{mg} / \mathrm{g}, 0.126 \pm 0.005 \mathrm{mg} / \mathrm{g}, 145.69 \pm 2.01 \mathrm{mg} / \mathrm{g}$ and $59.53 \pm 0.03 \%$ on dry basis respectively. The increase in drying temperature, significantly $(\mathrm{p}<0.5)$ decreased the polyphenol contents but had no significantly effect on the tannin, flavonoid content and antioxidant activity. The DPPH radical scavenging activity of leaves dried at $50^{\circ} \mathrm{C}$ was found to be maximum $(56.72 \pm 0.07 \%$ on $\mathrm{db})$ and minimum $(47.56 \pm 0.02 \%)$ at $70^{\circ} \mathrm{C}$. The natural fermentation significantly $(\mathrm{p}<0.05)$ increased the total phenol $(273.2 \pm 2.33 \mathrm{mg} / \mathrm{g})$, flavonoid $(0.408 \pm 0.08 \mathrm{mg} / \mathrm{g})$ and tannin $(3.56 \pm 0.11 \mathrm{mg} / \mathrm{g})$ content on dry basis. The increase in total phenol and flavonoid content exhibited the subsequent increment in the antioxidant activity $(87.69 \pm 0.02 \%)$. It was found that, nettle buds contained a number of health promoting bioactive compounds such as tannins, polyphenol and flavonoid and their concentration increased significantly by natural fermentation but were not significantly affected by drying temperature $\left(50-70^{\circ} \mathrm{C}\right)$.
\end{abstract}

\author{
Article Info \\ Article history: \\ Received date: 16 September 2019 \\ Accepted date: 19 July 2020
}

Keywords:

Nettle buds,

Sisnu,

Drying temperature,

Natural fermentation,

Phytochemicals

\section{Introduction}

Stinging nettle (Urtica parviflora), a genus of annual or perennial herbs, commonly known as stinging nettle is a medicinal herb belonging to Urticaceae family (Mishra \& Kharel, 2010). Four common species of Urticaceae used for vegetable purpose found in Indian region viz. dioica, girardinia, parviflora and trema, The species, Urtica parviflora, found in Nepal especially in middle and lower zone between 450 to $3500 \mathrm{~m}$ from sea level (Thapaliya, 2010). The species parviflora (Nepal-Gharaiya-Sisnu) is a slender, sparingly branched, perennial herb up to 3 $\mathrm{m}$ tall and copiously armed with stiff stinging hairs, abundantly found in the temperate region of
Himalayas. The nettle contains all the essential amino acids and the amount of bound amino acids is reported to be twice as high as alfalfa (Mishra \& Kharel, 2010). It is a good source of vitamins (vitamin A and thiamine) and minerals (potassium, calcium and iron).

Phytochemicals with different bioactivities in various vegetable crops are important components of a healthy diet. Many of these compounds appear to be responsible for the high antioxidant activity that is beneficial to human health (Chanli, 2012). These include cancer prevention, antibacterial, antifungal, antioxidative, hormonal action, enzyme stimulation and many more (Doss \& Anand, 2012). More than $80 \%$ of the population within developing countries relies on 
the use of herbal medicines for their primary healthcare due to their lower cost and time tested nature (Hussain et al., 2009). A number of phytochemical are known, some of which include: alkaloids, saponins, flavonoids, tannins, glycosides, anthraquinones, steroids and terpenoids.

According to Hur et al. (2014), fermentation increase antioxidant activity by increasing the release of flavonoids from plant based foods an useful method for increasing the supply of natural antioxidants in foods. It induces the structural breakdown of cell wall and hence the synthesis of various bioactive compounds. Katina et al. (2007), also reported that, plant parts have an increase in total phenols after fermentation, and that the observed antioxidant activity may be due to increased total phenolic content. These phenolic compounds can act as reducing agents, hydrogen donor and singlet oxygen quenchers (Miller \& Rice-Evans, 1997). The formation of hydroxyl methyl furfural which produces high antioxidant activity (Duenas, 2005; Siddhuraju, 2006). ViudaMartos et al. (2010), reported that the high phenolic and flavonoid content is a good indicator of their antioxidant capacity. As reported by Othman et al. (2009), the presence of lactic acid bacteria during fermentation might contribute to the simple phenolic conversion and the depolymerization of high molecular weight phenolic compounds.

At low temperature, deterioration of phytochemicals are slowed down (Li et al., 2012). Opposed to lower temperature, high temperature also brings a significant change in total phenolic, flavonoid, tannin content and antioxidant activity compared with its fresh form. However their concentration may vary according to the drying methods used and the duration of exposure to hot air (Michalczyk et al., 2009). Exposure to high temperature leads to discharge of phenolic compounds through disintegration of cellular constituents which then results in the migration of components, leading to losses by leakage or breakdown by various chemical reactions involving enzymes, light and oxygen as well as (Davey et al., 2001). According to Nazarni et al. (2015), tannin content in Crataeva nurvala was increased by 3-4 folds after fermentation; due to the leaching out of tannins through structural breakdown brought about by microbial enzymes (Rodriguez et al., 2009). Similarly, according to Reblova (2012), at high temperature , the total phenol and the antioxidant activity follows a decrease trend, which is caused by decrease in the ability of antioxidants to react with free radicals. The effect also coincides in case of tannins as the hydrolysable tannins get thermally degraded, causing an increase in nontannin content (Rakic et al., 2007). According to Mrad et al. (2012), the decrease in TPC during drying could be attributed to the binding of polyphenol with other compounds (proteins) or to alterations in the chemical structure of polyphenol which cannot be extracted or determined by available methods. Ancos et al. (2000), reported that the polyphenol compounds may also get deteriorated depending upon heat treatment. Methodology

\section{Materials and Methods}

The mature fresh leaves $(12 \mathrm{~kg})$ of common variety of nettle buds (U. parviflora) were collected from Dharan market, Nepal and were sorted, graded and washed with clean water. It was divided into four portions. The three portions (each approximately $2 \mathrm{~kg}$ ) were dried separately in cabinet drier at temperature $50 \pm 3^{\circ} \mathrm{C}, 60 \pm 3^{\circ} \mathrm{C}$ and $70 \pm 3^{\circ} \mathrm{C}$, till to $3 \% \mathrm{mc}$. The remaining portion $(4 \mathrm{~kg})$ was withered $(30-35 \% \mathrm{mc})$, roughly crushed in mortar and pestle which was then packed tightly in 10 clean dried needle perforated (4-8 pores/square inch) HDPE plastic jars for fermentation $\left(24 \pm 1^{\circ} \mathrm{C}\right.$ for 15 days). Samples were taken out from 4 th day onward to determine $\mathrm{pH}$ and acidity and then the opened jar was not reused for further fermentation or analysis. The effect of drying temperatures $(50 \pm 3$, $60 \pm 3,70 \pm 3^{\circ} \mathrm{C}$ ) and fermentation on the phytochemical (flavonoids, tannin, total polyphenol) content and antioxidant activity were studied.

\subsection{Preparation of sample extracts}

Briefly, $5 \mathrm{gm}$ of nettle buds leaves (fresh, dried and fermented) were grounded separately, in mortar and pestle with measured volume of $80 \%$ ethanol. The mixture was kept in a refrigerator at temperature $4^{\circ} \mathrm{C}$ for $24 \mathrm{~h}$. The mixture was then filtered using Whatman filter paper No. 42 (Rao et al., 1995).The volume of extract was made to $50 \mathrm{ml}$.

\subsection{Determination of total phenol}

It was carried out with Folin-Ciocalteau reagent (Thermo Fischer Scientific, India) as mentioned by Sadasivam \& Manickam (1996) with slight modification. Phenols react with phosphomoybdic acid in Folin-Ciocalteau reagent in alkaline medium producing a blue colored complex (molybdenum blue). Briefly, to $0.5 \mathrm{ml}$ of the sample extract, $1 \mathrm{ml}$ Folin- 
Ciocalteu reagent was mixed and incubated at room temperature $\left(28 \pm 5^{\circ} \mathrm{C}\right)$ for $15 \mathrm{~min}$. After then, $2.5 \mathrm{ml}$ of saturated sodium carbonate was added and further incubated for $30 \mathrm{~min}$ at room temperature and then, absorbance was measured at $760 \mathrm{~nm}$, using a Digital Spectrophotometer. The standard curve was prepared using $0-100 \mu \mathrm{g} / \mathrm{ml}$ solutions of gallic acid ( $98 \%$ assay) in ethanol. Total phenol values were calculated using the standard curve equation and expressed in terms of gallic acid equivalent $(\mathrm{mg} / \mathrm{ml})$ on dry mass.

\subsection{Determination of flavonoid}

Total flavonoid content was determined using a modified aluminum chloride assay method as described by (Barek et al., 2015). Briefly, to $2 \mathrm{ml}$ of sample extract, $0.2 \mathrm{~mL}$ of $5 \%$ sodium nitrate was mixed and stands for $5 \mathrm{~min}$. After then, $0.2 \mathrm{ml}$ aluminum chloride was mixed and again allowed to stand for $5 \mathrm{~min}$. This was followed by addition of $2 \mathrm{ml}$ of $1 \mathrm{~N}$ sodium hydroxide and finally volume was made up to $5 \mathrm{ml}$. The absorbance was measured after $15 \mathrm{~min}$ at $510 \mathrm{~nm}$, using a Digital Spectrophotometer. The flavonoid content in the extract was determined by the relation: 1 O.D. $=0.3987 \mathrm{mg}$.

\subsection{Determination of tannin}

The antioxidant activity of plant extract was determined using the colorimetric DPPH assay, as described by Blois (1958). Briefly, to $3 \mathrm{ml}$ of sample extract, $1 \mathrm{ml}$ of $0.1 \mathrm{mM}$ DPPH (HiMedia Laboratories Pvt. Ltd., $97 \%$ assay) solution was mixed vigorously and stand at room temperature for $30 \mathrm{~min}$. Then, absorbance was measured at $517 \mathrm{~nm}$ by using spectrophotometer. The antioxidant activity was calculated from the following equation:

Antioxidant Activity $(\%)=\frac{\text { Ao-A1 }}{\text { Ao }} \times 100$

Where, Ao is the absorbance of the control (Blois, 1958) and A1 is the absorbance of sample

\subsection{Determination of free radical scavenging capacity}

Tannin was determined by Folin-Denis method as described by Sadasivam and Manickam (1996). Briefly, to $1 \mathrm{ml}$ of the extract, $0.5 \mathrm{~mL}$ Folin-Denis reagent and $1 \mathrm{ml}$ of sodium carbonate was added. After making volume to $10 \mathrm{ml}$, it was left at room temperature for 30 minutes and then the absorbance was taken at $760 \mathrm{~nm}$ against a reagent blank in a spectrophotometer. The standard curve was prepared using $0-20 \mu \mathrm{g} / \mathrm{ml}$ solutions of tannic acid in ethanol. The amount of tannin was calculated using this standard curve equation and expressed in terms of tannin acid equivalent $(\mathrm{mg} / \mathrm{ml})$ of dry mass

\subsection{Statistical analysis}

The mean values of phytochemical content with standard deviation were computed. Data were subjected to Analysis of Variance at 0.95 confidence level using statistical software GenStat Release 12.1 (Discovery Edition 12 developed by VSN International Limited). Fischer's least significant difference (LSD) test was used to define the differences between the means at the 5\% significance level $(p<0.05)$.

\section{Results and Discussion}

\subsection{Effect of drying temperature on tannin and flavonoid content}

The tannin content in leaves was decreased from $1.02 \pm 0.08 \mathrm{mg} / \mathrm{g}$ (fresh leaves) to $0.94 \pm 0.04,0.72 \pm 0.15$ and $0.58 \pm 0.16 \mathrm{mg} / \mathrm{g}$ in leaves dried at 50,60 and $70^{\circ} \mathrm{C}$ respectively (Fig. 1 and Table 1). There was no significantly $(p>0.05)$ decreased of tannin content in leaves dried at $50^{\circ} \mathrm{C}$ but significantly, decreased in leaves dried at 60 and $70^{\circ} \mathrm{C}$. Similar observation on decrease in tannin was reported by Rakic et al., (2007) in oak plant and this may be due to the result of thermal degradation of hydrolysable tannins. The decrease in tannin was due to the result of thermal degradation of hydrolysable tannins (Rakic et al., 2007).

Table 1: Phytochemical content of dried leaves at different drying temperature

\begin{tabular}{|c|c|c|c|c|c|}
\hline Sample & & $\begin{array}{l}\text { Tannin } \\
\left(\mathrm{mg} \mathrm{g}^{-1}\right)\end{array}$ & $\begin{array}{l}\text { Flavonoid } \\
\left(\mathrm{mg} \mathrm{g}^{-1}\right)\end{array}$ & $\begin{array}{l}\text { Polyphenol } \\
\qquad\left(\mathrm{mg} \mathrm{g}^{-1}\right)\end{array}$ & $\begin{array}{l}\text { Antioxidant } \\
\text { activity (\%) }\end{array}$ \\
\hline Fresh & & $1.02 \pm 0.08^{\mathrm{a}}$ & $0.128 \pm 0.04^{\mathrm{a}}$ & $145.7 \pm 12.5^{\mathrm{a}}$ & $59.53 \pm 0.03^{\mathrm{a}}$ \\
\hline \multirow[t]{3}{*}{ Dry } & $50^{\circ} \mathrm{C}$ & $0.94 \pm 0.04^{\mathrm{ab}}$ & $0.277 \pm 0.044^{b}$ & $167.54 \pm 4.64^{b}$ & $64.83 \pm 0.01^{\mathrm{b}}$ \\
\hline & $60^{\circ} \mathrm{C}$ & $0.72 \pm 0.15^{\mathrm{b}}$ & $0.3417 \pm 0.01^{\mathrm{c}}$ & $196.68 \pm 0.09^{c}$ & $72.76 \pm 0.02^{\mathrm{c}}$ \\
\hline & $7^{\circ} \mathrm{C}$ & $0.58 \pm 0.16^{\mathrm{c}}$ & $0.382 \pm 0.025^{\mathrm{c}}$ & $259.77 \pm 3.68^{\mathrm{d}}$ & $84.23 \pm 0.05^{\mathrm{d}}$ \\
\hline
\end{tabular}

*Values are mean of three replicate determination and standard deviation. Figures in the row bearing the same superscripts are not significantly different $(p>0.05)$ 


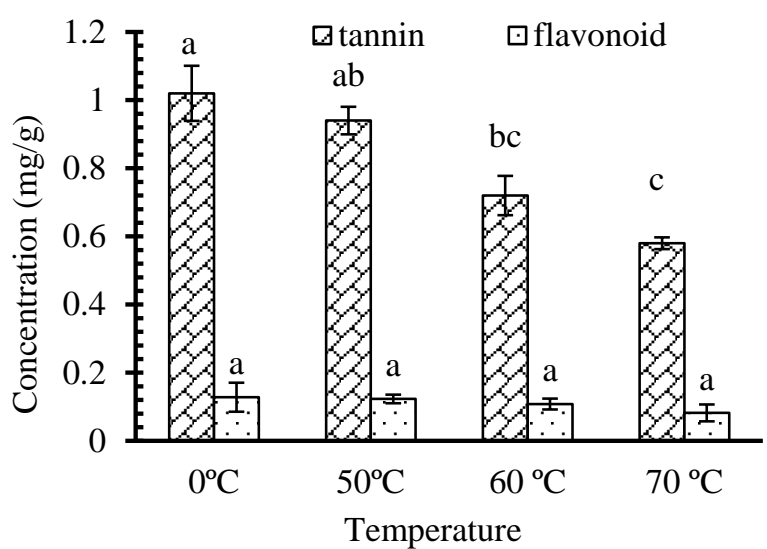

Fig. 1: Effect of drying temperature on tannin and flavonoid content.

Similarly, the flavonoid content decreased from $0.128 \pm 0.04 \mathrm{mg} / \mathrm{g}$ (fresh leaves) to $0.123 \pm 0.01$, $0.108 \pm 0.01$ and $0.082 \pm 0.02 \mathrm{mg} / \mathrm{g}$ in the leaves dried at $50,60,70^{\circ} \mathrm{C}$. Statistically, there was no significant (p>0.05) effect of drying temperature $\left(50-70^{\circ} \mathrm{C}\right)$ on flavonoid content. The leaves dried at $70^{\circ} \mathrm{C}$ showed a maximum loss followed by sample dried at 60 and then at $50^{\circ} \mathrm{C}$. The percentage loss in the flavonoid was observed to be $35.93 \%$ which was close to the observation made by Zhang et al. (2009). This might be due to thermal destruction of flavonoid and various chemical reactions involving enzymes, light and oxygen (Davey et al., 2001).

\subsection{Effect of drying temperature on polyphenol content and antioxidant activity}

The total phenol content (TPC) decreased significantly $(\mathrm{p}<0.05)$ from $145.7 \pm 12.5 \mathrm{mg} / \mathrm{g}$ (fresh leaves) to $103.45 \pm 6.72,85.54 \pm 10.9$ and $33.11 \pm 12.20$ $\mathrm{mg} / \mathrm{g}$ in leaves dried at 50,60 and $70^{\circ} \mathrm{C}$ respectively (Fig.2 and Table 1). But there was no significant decrease of TPC between leaves dried at $50^{\circ} \mathrm{C}$ and $60^{\circ} \mathrm{C}$. The maximum loss of TPC $(77.27 \%)$ was found at higher temperature, which was similar to that of Zhang et al. (2009). According to Mrad et al. (2012), the decrease in TPC during drying could be attributed to the binding of polyphenol with other compounds (proteins) or to alterations in the chemical structure of polyphenol which cannot be extracted or determined by available methods. Ancos et al. (2000), reported that the polyphenol compounds may also get deteriorated depending upon heat treatment.

Similarly, the antioxidant activity decreased from $59.53 \pm 0.03 \%$ (in fresh leaves) to $56.72 \pm 0.07 \%$, $50.09 \pm 0.05 \%$ and $47.56 \pm 0.02 \%$ in leaves dried at 50, 60 and $70{ }^{\circ} \mathrm{C}$ respectively. Statistically, there was no significant ( $p>0.05$ ) effect at drying temperature (50$60^{\circ} \mathrm{C}$ ) on antioxidant activity, but was significantly lowered at $70^{\circ} \mathrm{C}$. The percentage loss in the antioxidant activity was less than loss in TPC at each drying temperature. This was due to formation of hydroxyl methyl furfural which produces high antioxidant activity (Duenas, 2005; Siddhuraju, 2006).

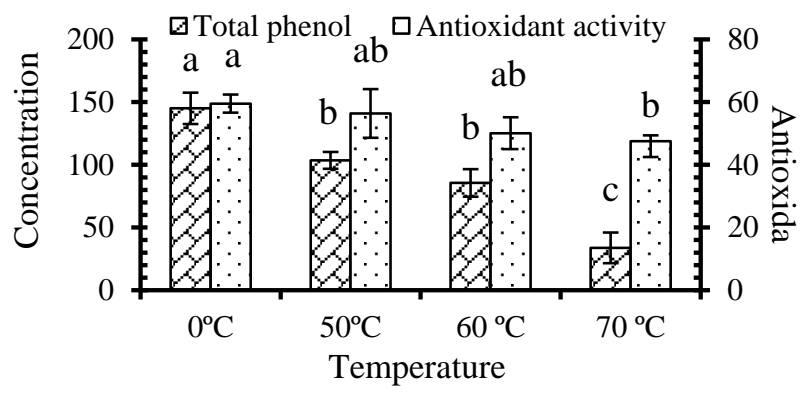

Fig. 2: Effect of drying temperature on total phenol and antioxidant activity.

\subsection{Effect of fermentation on tannin and flavonoid content}

The fermentation of fresh leaves at $24 \pm 1^{\circ} \mathrm{C}$, significantly $(\mathrm{p}<0.05)$ increased the tannin content with the days of fermentation from 4 to 12 days but was maximum $(3.56 \pm 0.11 \mathrm{mg} / \mathrm{g}$ on $\mathrm{db}$ ) on 15th day (Fig .3; Table 2). According to Nazarni et al. (2015), tannin content in Crataeva nurvala was increased by 3-4 folds after fermentation; due to the leaching out of tannins through structural breakdown brought about by microbial enzymes (Rodriguez et al., 2009).

Table 2: Phytochemical content of dried fermented leaves at different fermentation days.

\begin{tabular}{llllll}
\hline Sample & & Tannin $\left(\mathbf{m g ~ g}^{-\mathbf{1}}\right)$ & Flavonoid $\left(\mathbf{m g ~ g}^{-1}\right)$ & \multicolumn{1}{l}{ Polyphenol $\left(\mathbf{m g ~ g}^{-\mathbf{1}}\right)$} & Antioxidant activity (\%) \\
\hline Fresh & & $1.02 \pm 0.08^{\mathrm{a}}$ & $0.128 \pm 0.04^{\mathrm{a}}$ & $145.7 \pm 12.5^{\mathrm{a}}$ & $59.5 \pm 0.03^{\mathrm{a}}$ \\
\hline Fermented & Day 2 & $1.227 \pm 0.1^{\mathrm{ab}}$ & $0.148 \pm 0.001^{\mathrm{a}}$ & $146.9 \pm 3.18^{\mathrm{a}}$ & $60.5 \pm 0.02^{\mathrm{a}}$ \\
& Day 4 & $1.330 \pm 0.03^{\mathrm{b}}$ & $0.162 \pm 0.002^{\mathrm{a}}$ & $154.1 \pm 10.72^{\mathrm{a}}$ & $64.3 \pm 0.03^{\mathrm{a}}$ \\
& Day 6 & $1.657 \pm 0.08^{\mathrm{c}}$ & $0.278 \pm 0.07^{\mathrm{b}}$ & $171.3 \pm 11.2^{\mathrm{b}}$ & $69.1 \pm 0.21^{\mathrm{b}}$ \\
& Day 9 & $2.620 \pm 0.22^{\mathrm{d}}$ & $0.332 \pm 0.05^{\mathrm{bc}}$ & $230.2 \pm 4.66^{\mathrm{c}}$ & $78.5 \pm 0.02^{\mathrm{c}}$ \\
& Day 12 & $3.313 \pm 0.37^{\mathrm{e}}$ & $0.382 \pm 0.02^{\mathrm{cd}}$ & $268.89 \pm 5.88^{\mathrm{d}}$ & $87.3 \pm 0.02^{\mathrm{d}}$ \\
& Day15 & $3.56 \pm 0.11^{\mathrm{e}}$ & $0.408 \pm 0.08^{\mathrm{d}}$ & $273.2 \pm 2.33^{\mathrm{d}}$ & $87.6 \pm 0.02^{\mathrm{d}}$ \\
\hline
\end{tabular}

*Values are means \pm standard deviations for triplicate 


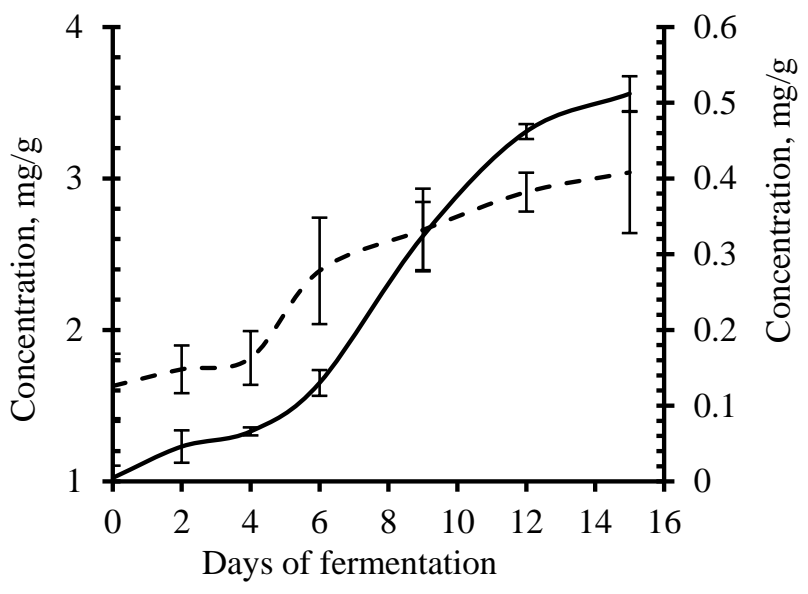

— Tannin - - - Flavonoid

Fig. 3: Effect of fermentation on tannin and flavonoid level.

Similarly, fermentation significantly $(\mathrm{p}<0.05)$ increased the flavonoid content with the days of fermentation from 6 to 12 days but was maximum $(0.408 \pm 0.08 \mathrm{mg} / \mathrm{g} \mathrm{db})$ on 15 th day (Fig 3 and Table 2). According to Nazarni et al. (2015), flavonoid content in Crataeva nurvala increased by 2-3 fold after fermentation, due to hydrolysis of flavonoid compounds by microbial enzymes like $\beta$-glucosidase there by facilitating the flavonoid extraction (Hur et al., 2014).

\subsection{Effect of fermentation on total polyphenol content and antioxidant activity}

Statistically, fermentation of fresh leaves, significantly $(\mathrm{p}<0.05)$ increased the total polyphenol content (TPC) with the days of fermentation from 6 to 12 days but was maximum $(273.2 \pm 2.33 \mathrm{mg} / \mathrm{g} \mathrm{db})$ on 15th day (Fig 4; Table 2). Ng et al. (2011), reported that Anoectochilus formosanus plant had an increase in TPC after fermentation. Nazarni et al. (2015), also reported a greater TPC in fermented product.

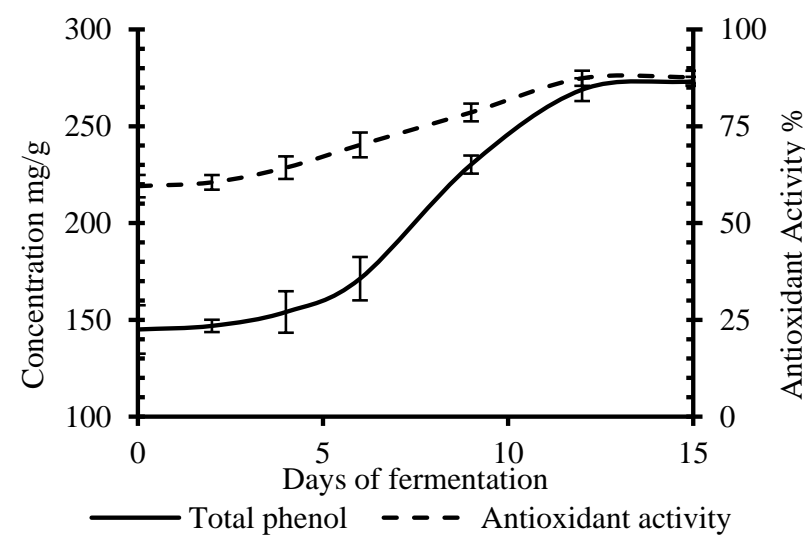

Fig. 4: Effect of fermentation on total phenol level and antioxidant activity

The released of microbial enzymes during fermentation; produced more free form of plant polyphenol (Messens \& De Vuyst, 2002). As reported by Othman et al. (2009), the presence of lactic acid bacteria during fermentation might contribute to the simple phenolic conversion and the depolymerization of high molecular weight phenolic compounds.

Similarly, fermentation of fresh leaves, significantly $(\mathrm{p}<0.05)$ increased the antioxidant activity with the days of fermentation from 6 to 12 days but was found maximum $(87.69 \pm 0.02 \%)$ on 15 th day (Fig 4 and Table 2). Viuda-Martos et al. (2010), reported that the high phenolic and flavonoid content is a good indicator of their antioxidant capacity.

\subsection{Changes in pH and acidity during fermentation of fresh leaves}

The relation obtained of $\mathrm{pH}$ and acidity during fermentation was similar to that of fermentation of other product like Gundruk (Nepalese traditional fermentation food). Acidity and $\mathrm{pH}$ of fresh leaves were found to be $0.2 \%$ as lactic acid and 6.1 respectively. The $\mathrm{pH}$ was decreased and acidity was increased significantly $(\mathrm{p}<0.05)$ with days of fermentation till to 12 days aft er then it decreased insignificantly (Fig.5) which might be due to termination of fermentation (Mishra \& Kharel, 2007).

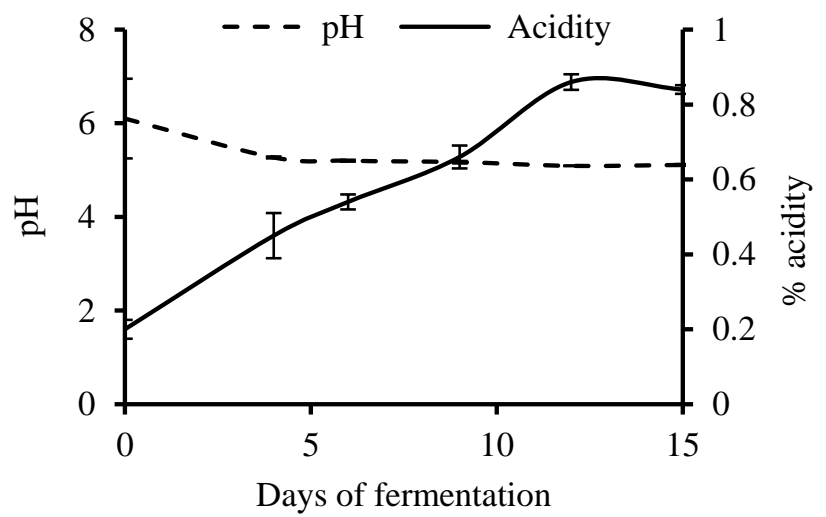

Fig. 5: Changes on $\mathrm{pH}$ and acidity (as lactic acid) during fermentation

\section{Conclusions}

Stinging nettle (Nepalese tongue: sisnu) leaves contain numerous amounts to phytochemicals (tannin, flavonoid and polyphenol) compounds exhibiting antioxidant activity. The total phenol content of dried leaves decrease significantly $(\mathrm{p}<0.05)$ with increased of drying temperature $\left(50-70^{\circ} \mathrm{C}\right)$, however, there was 
insignificant loss in tannin, flavonoid level and antioxidant activity. Fermentation $\left(24 \pm 1^{\circ} \mathrm{C}\right)$ of sisnu significantly increased the total phenol, flavonoid and tannin level and the antioxidant activity. The phytochemical level was found to be increase significantly with the days of fermentation. The fermented leaves had a potent biological activities compared to its fresh form and could be subjected to the isolation of therapeutic compounds as well as development of functional foods.

\section{Acknowledgments}

The authors appreciate and are thankful to all the faculties and staffs of the Department of Food Technology, Central Campus of Technology, Dharan, Nepal for their support and technical assistance.

\section{Conflicts of Interest}

The authors state no conflicts of interest. The authors alone are responsible for composing the paper.

\section{Funding}

This research did not get a particular award or grant from subsidizing organizations in general society, business, or not-for-profit driven sectors

\section{References}

Abidemi, O. O. (2013). Phytochemicals and spectrophotometric determination of metals in various medicinal plants in Nigeria. International Journal of Engineering Science Invention, 2(5), 51-54.

Ancos, B., Reglero, G., \& Cano, M. P. (2002). Frozen storage effects on anthocyanins and volatile compounds of raspberry fruit. Journal of Agricultural and Food Chemistry, 48, 873-79.

Barek, M. L., \& Hasmadi, M. (2015). Effect of different drying methods on phytochemicals and antioxidant properties of unfermented and fermented teas from Sabah Snake Grass (Clinacanthus nutans Lind.) leaves. International Food Research Journal, 22(2), 661-670.

Blois, M. S. (1958). Antioxidant determined by the use of a stable free radical. Nature, 181, 199-200.

Chanli, H. (2012). Factors affecting phytochemical composition and antioxidant activity of Ontario vegetable crops. M. Tech Thesis. The University of Guelph, Ontario, Canada.
Davey, M. W., Van-Montangu, M., Sanmarti, M., \& Kannelis, M. (2001). Plant L-ascorbic acid: chemistry, function, metabolism, bioavailability and effects of processing. Journal of the Science of Food and Agriculture, 80, 825-60.

Doss, A., \& Anand, S.P. (2012). Preliminary Phytochemical Screening of Asteracantha longi folia and Pergularia daemia. World Applied Sciences Journal, 18 (2), 233-35.

Duenas, M. (2005). Bioactive phenolic compounds of cowpeas (Vigna sinensis L.) modifications by fermentation with natural microflora and with Lactobacillus plantarum. Journal of the Science of Food and Agriculture, 85(2), 297-304.

Hur, S. J., Lee, S. Y., Kim, Y. C., Choi, I., \& Kim, G. B. (2014). Effect of fermentation on the antioxidant activity in plant-based foods. Food chemistry, 160, 346-356.

Hussain, K., Majeed, M. T., Ismail, Z., Sadikun, A., \& Ibrahim, P. (2009). Traditional and complementary medicines: quality assessment strategies and safe usage. Southern med review, 2(1), 19.

Katina, K., Laitila, A., Juvonen, R., Liukkonen, K. H., Kariluoto, S., Piironen, V., ... \& Poutanen, K. (2007). Bran fermentation as a means to enhance technological properties and bioactivity of rye. Food microbiology, 24(2), 175-186.

Li, H., Tsao, R., \& Deng, Z. (2012). Factors affecting the antioxidant potential and health benefits of plant foods. Canadian journal of plant science, 92(6), 1101-1111.

Messens, W., \& De Vuyst, L. (2002). Inhibitory substances produced by Lactobacilli isolated from sourdoughs - a review. International journal of food microbiology, 72(1-2), 31-43.

Michalczyk, M., Macura, R., \& Matuszak, I. (2009). The effect of air-drying, freeze-drying and storage on the quality and antioxidant activity of some selected berries. Journal of Food Processing and Preservation, 33(1), 11-21.

Miller, N. J., \& Rice-Evans, C. A. (1997). Factors influencing the antioxidant activity determined by the ABTS•+ radical cation assay. Free radical research, 26(3), 195-199.

Mishra, A., \& Kharel, G. P. (2010). Preservation and Quality Evaluation of Sisnu (Urtica plaviflora) by 
making Gundruk like fermented product. Journal of Food Science and Technology Nepal, 6, 114-117.

Mrad, N. D., Boudhrioua, N., Kechaou, N., Courtois, F., \& Bonazzi, C. (2012). Influence of air drying temperature on kinetics, physicochemical properties, total phenolic content and ascorbic acid of pears. Food and bioproducts processing, 90(3), 433-441.

Nazarni, R., Purnama, D., Umar, S., \& Eni, H. (2016). The effect of fermentation on total phenolic, flavonoid and tannin content and its relation to antibacterial activity in jaruk tigarun (Crataeva nurvala, Buch HAM). International Food Research Journal, 23(1).

Ng, C. C., Wang, C. Y., Wang, Y. P., Tzeng, W. S., \& Shyu, Y. T. (2011). Lactic acid bacterial fermentation on the production of functional antioxidant herbal Anoectochilus formosanus Hayata. Journal of bioscience and bioengineering, 111(3), 289-293.

Othman, N. B., Roblain, D., Chammen, N., Thonart, P., \& Hamdi, M. (2009). Antioxidant phenolic compounds loss during the fermentation of Chétoui olives. Food Chemistry, 116(3), 662-669.

Rakić, S., Petrović, S., Kukić, J., Jadranin, M., Tešević, V., Povrenović, D., \& Šiler-Marinković, S. (2007). Influence of thermal treatment on phenolic compounds and antioxidant properties of oak acorns from Serbia. Food Chemistry, 104(2), 830834.

Rao, V. V., Dwivedi, S. K., Swarup, D., \& Sharma, S. R. (1995). Screening of hypoglycemic action in certain indigenous drugs. Current Science, 69, 93233.

Réblová, Z. (2012). Effect of temperature on the antioxidant activity of phenolic acids. Czech Journal of Food Sciences, 30(2), 171-175.

Rodríguez, H., Curiel, J. A., Landete, J. M., de las Rivas, B., de Felipe, F. L., Gómez-Cordovés, C., ... \& Muñoz, R. (2009). Food phenolics and lactic acid bacteria. International journal of food microbiology, 132(2-3), 79-90.

Sadasivam, S. (1996). Biochemical methods. New age international.

Siddhuraju, P. (2006). The antioxidant activity and free radical-scavenging capacity of phenolics of raw and dry heated moth bean (Vigna aconitifolia)(Jacq.) Marechal seed extracts. Food Chemistry, 99(1), 149-157.

Viuda-Martos, M., El Gendy, A. E. N. G., Sendra, E., Fernandez-Lopez, J., Abd El Razik, K. A., Omer, E. A., \& Perez-Alvarez, J. A. (2010). Chemical composition and antioxidant and anti-Listeria activities of essential oils obtained from some Egyptian plants. Journal of agricultural and food chemistry, 58(16), 9063-9070.

Zhang, M., Hettiarachchy, N. S., Horax, R., Chen, P., \& Over, K. F. (2009). Effect of maturity stages and drying methods on the retention of selected nutrients and phytochemicals in bitter melon (Momordica charantia) leaf. Journal of food science, 74(6), C441-C448.

(C) 2020 by the authors. Submitted for possible open access publication under the terms and conditions of the Creative Commons Attribution (CC BY) license (http://creativecommons.org/licenses/by/4.0/).

How to cite: Adhikari, B., \& Ale, S. (2020). Effect of Drying Temperature and Natural Fermentation on the Phytochemical Composition of Stinging Nettle Buds (Urtica parviflora). Himalayan Journal of Science and Technology, 3-4, 1-7. 